\title{
Transfotografia: o pixel em multidão
}

Patrícia Beatriz Argollo Gomes Kirst

Orientador: Tania Mara Galli Fonseca

Coorientador: Maria Cristina Villanova Biazus

Data da defesa: 10 de março de 2010

A tese "Transfotografia: O Píxel em Multidão" circunscreve o conceito de trans com vistas a problematizar a fotografia digital, em processo de manipulação, bem como os sujeitos, que operam tal processo em interação criativa, entendidos sob a luz do conceito de multidão (Antônio Negri e Michael Hardt, 2005). A tentativa de produzir conhecimento em torno da fotografia digital em seu estado instituinte aponta para uma dimensão múltipla e ambígua e, pode assim, movimentar-se para além de coordenadas lineares: eis o movimento transversal que atravessa toda a discussão proposta. O estudo da imagem fotográfica digital presta-se à transdisciplinariedade localizada, aqui, entre a Psicologia Social, a Informática na Educação e a Filosofia. Colocar a imagem em emergência, em seus universos conceituais e, em sua imanência, requer pensá-la no limite. Tal limite situa-se em cada píxel que abriga a molecularidade que, quando acionada, pode tornar-se diferença e potência para passagem de uma imagem à outra. Pensar a imagem fotográfica digital em estado processual e molecular segue as marcas da subversão da forma, da verdade e da representação, levada por pontos de vista fugidios que constituem, assim, o horizonte desta tese. Este estudo está inscrito em um modo inventivo e experimental de produzir ciência, trazendo à tona um olhar-travessia em uma cartografia que utiliza a transfotografia como passagem para discutir o contemporâneo em algumas de suas faces tecnológicas e de subjetivação. Sua formulação mais precisa, poder-se-ia expressar do seguinte modo: Como a transfotografia pode operar como dispositivo clínico-político na multidão?

Palavras-chave: Transfotografia. Transversalidade. Subjetivação-Educação. Multidão.

Referência:

KIRST, Patrícia Beatriz Argollo Gomes. Transfotografia: o pixel em multidão. Orientador: Profa. Dra. Tania Mara Galli Fonseca. Coorientador: Profa. Dra. Maria Cristina Villanova Biazus. Tese (Doutorado) - Programa de Pós-Graduação em Informática na Educação, CINTED/UFRGS, 2010, Porto Alegre, BR-RS. 